\title{
PENGARUH FAKTOR-FAKTOR KEUANGAN PERUSAHAAN TERHADAP KEBIJAKAN DIVIDEN
}

\author{
M. Y. Dedi Haryanto \\ STIE Musi, Palembang \\ mydediharyanto@gmail.com
}

\begin{abstract}
This research aims to know the influence of the liqudity, growth, profitability and efficiency to dividend policy. The population of this research are companies listed on the Indonesia stock exchange and the sample frame use the list of the 50 leading companies in market capitalization in 2012. The sampling methode is purposive sampling technique with two criteria and final sample are 36 listed company. Data was collected from the Indonesian Capital Market in 2012 with research period 20082010. This research use multiple regression to analysis data. There are one dependent variables and four independent variables. The results showed that at the level of $95 \%$, ROE, DER, and OPM influence dividend policy while net income growth does not affect the dividend policy. But with $90 \%$ confidence, results showed that net income growth (GROW) affect dividend policy. So it can be concluded that corporate financial factors influence the dividend policy.
\end{abstract}

Keywords: dividend policy, DER, net income growth, ROE, and OPM.

\section{PENDAHULUAN}

Pembagian dividen dapat digunakan oleh manajemen untuk meningkatkan harga sahamnya. Deitiana (2011) menyebutkan bahwa kebijakan dividen merupakan keputusan yang diambil perusahaan untuk menentukan berapa besar bagian dari laba bersih yang diperoleh untuk dibagikan sebagai dividen atau laba ditahan. Pembagian dividen ternyata juga mampu menyampaikan informasi mengenai prospek perusahaan. Abbe (2001) menyebutkan bahwa informasi perubahan dividen memiliki kandungan perubahan laba masa depan.

Analisis dividen pada emiten nonkeuangan di Bursa Efek Indonesia pada periode 1991-2006 menunjukkan bahwa 60\% korporasi penghasil laba membagi dividen dengan rasio $25 \%$ dari laba bersih. Jika dilihat setelah periode krisis 1998, jumlah perusahaan untung yang membagikan dividen ternyata hanya $40 \%$ dengan rasio payout sebesar $20 \%$. Angka ini turun dari periode sebelum krisis dengan $80 \%$ emiten penghasil laba membayar dividen 35\% dari laba bersih. Tidak semua perusahaan yang mendapat laba membagikan dividen seperti PT Hero Supermarket yang tidak pernah membagikan dividen 10 tahun terakhir dan PT. Bakrie Brothers (BNBR) selama 12 tahun meskipun sering mengalami keuntungan.

Secara konsep, dividen adalah laba yang dibagikan. Hanya perusahaan mendapat laba yang dapat membagikan dividen dan perusahaan yang rugi tidak mempunyai kewajiban untuk ini. Perusahaan rugi yang memaksakan diri membagikan dividen dapat mengubur dirinya melalui likuidasi namun ada juga yang tetap membagikan dividen karena dianggap 
memiliki sentimen positif. Beberapa penelitian mengenai dividen menguji reaksi pasar terhadap pengumuman dividen. Bandi dan Jogiyanto (2000) menunjukkan bahwa ada reaksi pasar disekitar pengumuman dividen yang dilihat dari reaksi harga dan volume. Penelitian reaksi ini kemudian berkembang dengan melihat reaksi terhadap kebijakan dividen pada waktu ex-dividend day. Pujiono (2992), Sularso (2003) dan Siaputra dan Adwin (2006) membuktikan pengaruh pengumuman dividen disekitar tanggal exdividen date. Kemudian Apriani (2005) meneliti mengenai pola kebijakan dividen. Ia meneliti reaksi pasar terhadap pengumuam dividen naik atau turun. Penelitiannya menyimpulkan bahwa pasar bereaksi kuat terhadap pengumuman kenaikan atau penurunan dividen. Semua hasil penelitian ini menunjukkan bahwa dividen merupakan aksi korporasi perusahaan yang penting yang mampu mempengaruhi ekspektasi investor.

PT Indofood Sukses Makmur (INDF) memutuskan untuk membagikan dividen 2005 sebesar Rp5 per saham atau setara dengan 39\% dari perolehan laba bersih 2005 yang mencapai Rp124 miliar. Dibandingkan tahun sebelumnya, dividen yang dibagikan tersebut turun drastis. Untuk tahun buku 2004, INDF membagikan dividen sebesar Rp17,5 per saham atau setara dengan 39\% dari laba bersih 2004 yang mencapai Rp 386,9 miliar. Dengan demikian, rasio pembayaran dividen tidak berubah meskipun nilai nominal dividen mengalami penurunan. Penurunan laba bersih dan dividen yang dibagikan tersebut sebagai dampak dari meningkatnya beban usaha, beban bunga, dan masih tingginya rugi selisih kurs. Meski penjualan Indofood sepanjang 2005 naik 4,7 \% menjadi Rp18,76 triliun, namun hal itu tidak dapat menutupi peningkatan beban usaha, beban bunga, dan rugi kurs. (http://www. investorindonesia.com)

Cuplikan berita di atas merupakan suatu informasi mengenai kebijakan dividen perusahaan, dalam contoh ini adalah Indofood. Ketika sebuah perusahaan memperoleh laba bersih (net income) dan tingkat cash flows pada suatu periode tertentu, manajemen dihadapkan pada keputusan pemanfaatan laba tersebut. Dua alternatif penggunaan utama laba adalah: (1) dibagikan sebagai dividen atau (2) ditahan sebagai laba ditahan (retained arnings). Keputusan inilah yang dikenal sebagai kebijakan dividen, yaitu menentukan seberapa besar atau proporsi laba yang akan dibagikan sebagai dividen.

Dalam mendesain dan mengimplementasikan kebijakan tersebut, terdapat tradeoff yang harus diperhatikan. Jika perusahaan meningkatkan dividen, pemegang saham atau pemilik perusahaan akan memperoleh cash flows namun pertumbuhan perusahaan berpotensi menurun karena cash flows tersebut semestinya dapat digunakan untuk reinvestasi. Di sisi lain, jika perusahaan mengurangi dividen, pertumbuhan perusahaan mungkin akan meningkat namun pemegang saham akan menerima cash flows yang lebih sedikit sehingga secara sekilas kemakmuran pemegang saham juga terpengaruh. Setyawan (2009) menunjukkan bahwa memang terjadi interaksi antara keputusan dividen dan struktur modal untuk meminimumkan biaya keagenan.

Hal ini menunjukkan bahwa keputusan kebijakan dividen sangat dipengaruhi oleh kondisi keuangan perusahaan. Kemampuan perusahaan membagikan dividen tergantung dari faktor-faktor keuangan perusahaan. Hery (2009) membuktikan bahwa terdapat pengaruh yang signifikan antara laba bersih dengan dividen kas. Ia juga membuktikan bahwa arus kas operasi mempengaruhi dividen kas. Sedangkan Putra dan Yunia (2009) meneliti tentang faktor-faktor yang mempengaruhi keputusan pembagian dividen. Hasilnya menunjukkan bahwa volatilitas ROE dan kebijakan dividen tahun lalu menentukan keputusan pembagian dividen sedangkan variabel earning, retain earning, ROE, ukuran perusahaan, utang dan struktur kepemilikan tidak berpengaruh signifikan. 
Kondisi keuangan perusahaan saat ini dan masa mendatang memang menjadi dasar pertimbangan manajemen dalam memutuskan kebijakan dividen. Pembagian dividen memiliki dampak keuangan bagi perusahaan. Penelitian ini ingin menguji faktor-faktor keuangan yang digunakan manajemen dalam menentukan kebijakan dividen. Faktor keuangan yang diteliti meliputi faktor likuiditas, efisiensi, profitabilitas, dan pertumbuhan.

\section{REVIEW LITERATUR DAN HIPOTESIS}

\section{Dividen dan Kepentingan Pemegang Saham}

Dividen sebagai apresiasi perusahaan kepada pemegang saham. Pada dasarnya tujuan perusahaan adalah memaksimumkan nilai pemegang saham. Dalam teori keagenan, terdapat dua pihak utama dalam sebuah perusahaan yaitu pemilik dan manajemen. Demi mencapai tujuan perusahaan, manajemen sebagai pihak yang diberi amanat mengelola perusahaan, melakukan serangkaian keputusan baik yang bersifat strategis maupaun taktis operasional. Efektifitas keputusan yang diambil manajemen akan menentukan sejauh mana tujuan perusahaan dapat dicapai. Prestasi manajemen dalam mengelola perusahaan dipertanggungjawabkan kepada para pemilik atau pemegang saham. Dengan demikian, maka kepentingan pemegang saham merupakan fokus manajemen dalam mencapai tujuan perusahaan. (Basir dan Hendy, 2005: hal. 75)

Dividen merupakan hak pemegang saham. Namun pembagian dividen bukan merupakan kewajiban tetapi bersifat kebijakan manajemen yang disebut kebijakan dividen., Seandainya perusahaan mengalami kerugian maka ia boleh tidak membagikan dividen. Namun ada perusahaan yang tetap membagikan dividen walaupaun tidak memperoleh laba. Hal ini menunjukkan bahwa kebijakan dividen mempunyai arti penting dalam kelangsungan hidup perusahaan.
Dalam dunia keuangan, terdapat lima konsep tentang kebijakan dividen, yaitu:

- Irrelevance theory. Teori ini menganggap bahwa kebijakan dividen tidak membawa dampak apa-apa bagi nilai perusahaan. Jadi, peningkatan atau penurunan dividen oleh perusahaan tidak akan mempengaruhi nilai perusahaan.

- Agency theory. Teori ini berpendapat bahwa dividen dapat digunakan untuk mengurangi agency cost. Jika perusahaan membagikan dividennya maka manajemen akan memenuhi kebutuhan pendanaan dari pihak luar. Jadi kreditorlah yang kemudian akan mengawasi kondisi dan kinerja perusahaan.

- Bird-in-the-hand theory. Teori ini berpendapat bahwa investor menyukai dividen karena kas di tangan lebih bernilai daripada kekayaan dalam bentuk lain. Konsekuensinya, harga saham perusahaan akan sangat ditentukan oleh besarnya dividen yang dibagikan. Dengan demikian, semakin tinggi dividen yang dibagikan, semakin tinggi pula nilai perusahaan.

- Residual Dividend Theory. Teori ini menganggap bahwa laba yang dibagikan merupakan sisa laba yang sudah digunakan terlebih dahulu untuk capital investement. Dengan demikian investasi yang dilakukan tersebut akan dapat meningkatkan nilai saham dimasa depan.

- Tax preference theory. Menurut teori ini, investor tidak terlalu menyukai dividen karena dividen tidaklah tax deductible.

Meskipun lima konsep tersebut dianggap sebagai teori-teori utama mengenai kebijakan dividen, perkembangan ilmu keuangan modern memunculkan pendekatan baru yang lebih relevan dan lebih mampu menjelaskan kebijakan dividen dalam dunia bisnis praktis, yaitu signalling theory. Pengumuman dividen diyakini mempunyai informasi dan membawa sinyal tentang laba bersih saat ini dan potensi perusahaan 
di masa mendatang. Model signalling dividen mulai berkembang pada akhir tahun 1970-an di Amerika. Ide dasar dalam model ini adalah bahwa perusahaan melakukan penyesuaian dividen untuk menunjukkan sinyal akan prospek perusahaan. Yang membuat metode ini menjadi kompleks adalah kenyataan bahwa dividen yang meningkat oleh suatu perusahaan dapat diterjemahkan sebagai sinyal positif, namun dapat pula diartikan sebagai sinyal negatif.

\section{Pola Kebijakan Dividen dan Mekanisme Pembagian Dividen}

Dividen memang bukan kewajiban suatu perseroan, walaupun merupakan hak pemegang saham. Ia baru menjadi kewajiban atau hutang setelah diputuskan dan diumumkan. Kebijakan dividen adalah budaya perusahaan. Di Indonesia, perusahaan publik memang diwajibkan Otoritas Pasar Modal untuk menjelaskan Kebijakan Dasar Dividen (KDD) dalam prospektus yang mereka terbitkan dalam rangka initial public offering. Ada perusahaan yang menetapkan KDD stabil dalam rupiah, ada pula yang menetapkan KDD stabil pay out ratio (Constant payout ratio divident policy) dan ada segelintir yang dengan berani menetapkan KDD dengan pertumbuhan stabil dalam rupiah (regular dividen policy) atau kebijakan dividen yang didasarkan pembayaran dividen rendah yang teratur, ditambah dengan dividen ekstra jika ada jaminan pendapatan (LowRegular-an-Extra Dividend Policy). Sebagian perusahaan tbk di Indonesia menggunakan KDD stabil pay out ratio). Otoritas hanya mewajibkan perseroan menjelaskan KDD, teknis bagaimana proses pengambilan keputusan, besarnya, dan cara pembayarannya, diserahkan untuk diatur dalam Anggaran Dasar Perseroan dan atau kebijakan perseroan lainnya.

Sampai di sini, kebijakan dividen masih merupakan bagian dari budaya perusahaan. Karena itu perusahaan publik di Indonesia, pada umumnya mengumumkan dividen dua kali setiap tahun anggaran. Kebiasaan semacam itu pula yang kemudian menjadi terminologi sendiri di pasar modal, yaitu dengan dikotomi "dividen interim" dan "dividen final". Dividen interim biasanya diputuskan oleh Rapat Direksi di tengah-tengah perjalanan tahun anggaran, setelah melihat kinerja perseroan selama semester pertama tahun anggaran.

Mayoritas anggaran dasar perusahaan publik yang tahun anggarannya berakhir 31 Desember menetapkan bahwa RUPS Tahunan wajib diselenggarakan sebelum akhir Juni tahun berikutnya. Otoritas Pasar Modal mewajibkan perseroan terbuka itu menyampaikan laporan keuangan yang telah diaudit paling lambat 31 Maret tahun berikutnya, setelah tahun buku perseroan berakhir. Itu sebabnya, dividen final pada umumnya diputuskan pada RUPS Tahunan yang diselenggarakan pada bulan-bulan April Mei - Juni setiap tahun.

Pengambilan keputusan pembagian dividen oleh manajemen dapat menyebabkan perubahan nilai saham perusahaan. Dalam kondisi perekonomian normal, tindakan manajemen yang menyebabkan pendapatan dividen meningkat (changes in expected return) akan meningkatkan nilai saham. Sebaliknya, tindakan manajemen yang dapat meningkatkan risiko (changes in risk) akan meningkatkan return yang diharapkan dan menurunkan nilai saham dan sebaliknya. Karena keputusan manajemen, terutama yang berkaitan dengan masalah finansial perusahaan, seringkali mempengaruhi baik risiko maupun return secara bersamaan, maka dampak terhadap nilai saham tergantung kepada ukuran besar-kecilnya perubahan variabel-variabel tersebut.

Dampak lain yang ditimbulkan oleh kebijakan dividen adalah bahwa kebijakan tersebut secara langsung akan berpengaruh negatif dengan leverage keuangan perusahaan (Pujiono, 2002). Artinya, debt to equity ratio akan meningkat sesuai dengan proporsi dividen yang akan dibagikan. Meningkatnya nilai leverage 
maka penilaian terhadap perusahaan menjadi buruk yang selanjutnya akan mempengaruhi harga saham di pasar.

\section{Faktor-Faktor Keuangan Penentuan Kebija- kan Dividen}

Dalam mengelola bisnis manajemen seringkali memerlukan data-data yang berasal dari laporan operasi internal, harian surat kabar, majalah bisnis dan banyak sumber yang lain. Walsh (2003: hal 7) menyatakan bahwa kondisi perusahaan menjadi salah satu sumber penting bagi manajemen mengelola bisnisnya. Ada beberapa isu penting dalam bisnis yaitu aktiva, laba, pertumbuhan dan arus kas. Keempat variabel ini saling berhubungan. Terdapat keseimbangan yang dapat dipertahankan diantara keempat variabel itu dan dari keseimbangan ini akan dihasilkan nilai perusahaan (corporate value). Nilai perusahaan inilah yang menjadi alasan sebagian aktivitas bisnis atau stakeholder menfokuskan perhatian pada rasio-rasio bisnis yang menentukan nilai perusahaan. Rasio-rasio inilah yang menjadi perhatian manajemen dalam menentukan kebijakan dividen.

Dividen merupakan kas keluar bagi perusahaan yang dapat mempengaruhi kondisi keuangan perusahaan di masa mendatang. Dalam membagikan dividen, perusahaan harus memperhatikan beberapa faktor, antara lain:

a. Kesempatan Investasi, Kebijakan dividen perusahaan jangan sampai mengorbankan proyek yang dapat meningkatkan value pemegang saham di masa yang akan datang. Semakin besar kesempatan investasi maka dividen yang bisa dibagikan akan semakin sedikit.

b. Profitabilitas dan Likuiditas, Kebijakan dividen perusahaan sebaiknya memperhitungkan profitabilitas dan likuiditas perusahaan. Aliran kas atau profitabilitas yang baik bisa membayar dividen atau meningkatkan dividen. Alasan lain pembagian dividen adalah untuk menghindari akuisisi oleh perusahaan lain.

c. Akses ke Pasar Keuangan, Jika perusahaan mempunyai akses ke pasar keuangan yang baik, perusahaan bisa membayar dividen lebih tinggi. Akses yang baik bisa membantu perusahaan memenuhi kebutuhan likuiditasnya.

d. Stabilitas Pendapatan, Jika pendapatan perusahaan relatif stabil, aliran kas di masa mendatang bisa diperkirakan dengan lebih akurat. Perusahaan semacam itu bisa membayar dividen yang lebih tinggi. Hal yang sebaliknya terjadi untuk perusahaan yang mempunyai pendapatan yang tidak stabil. Ketidakstabilan aliran kas di masa mendatang membatasai kemampuan perusahaan membayar dividen yang tinggi.

Pada praktiknya, ada beberapa faktor lain yang mempengaruhi manajemen dalam menentukan pembagian dividen seperti perjanjian hutang. Pada umumnya perjanjian hutang antara perusahaan dengan kreditor membatasi pembayaran dividen. Misalnya, dividen hanya dapat diberikan jika kewajiban hutang telah dipenuhi perusahaan dan/atau rasio-rasio keuangan menunjukkan perusahaan dalam kondisi sehat. Faktor lainnya adalah tersedianya kas. Dividen berupa uang tunai hanya dapat dibayar jika tersedianya uang tunai yang cukup. Jika likuiditas baik, perusahaan dapat membayar dividen.

Pembagian dividen oleh manajemen kadangkali bermotif pengendalian. Jika manajemen ingin mempertahankan kontrol terhadap perusahaan, ia cenderung untuk segan menjual saham baru sehingga lebih suka menahan laba guna memenuhi kebutuhan dana/baru. Akibatkanya dividen yang dibayar menjadi kecil. Faktor ini menjadi penting pada perusahaan yang relatif kecil. Selain itu pembagian dividen juga ditujukan untuk memenuhi kebutuhan dana untuk investasi. Perusahaan yang berkembang selalu 
membutuhkan dana baru untuk diinvestasikan pada proyek-proyek yang menguntungkan. Sumber dana baru yang merupakan modal sendiri (equity) dapat berupa penjualan saham baru dan laba ditahan. Manajemen cenderung memanfaatkan laba ditahan karena penjualan saham baru menimbulkan biaya peluncuran saham (flotation cost). Oleh karena itu semakin besar kebutuhan dana investasi, semakin kecil dividen payout ratio.

Keputusan pembagian dividen merupakan keputusan jangka panjang karena besarnya tergantung dari fluktuasi laba. Jika laba konstan maka perusahaan dapat membagikan dividen yang relatif besar tanpa takut harus menurunkan dividen jika laba tiba-tiba merosot. Sebaliknya jika laba perusahaan berfluktuasi, dividen sebaiknya kecil agar kestabilannya terjaga. Selain itu, perusahaan dengan laba yang berfluktuasi sebaiknya tidak banyak menggunakan hutang guna mengurangi risiko kebangkrutan. Konsekuensinya laba ditahan menjadi besar dan dividen mengecil.

\section{Pengembangan Hipotesis}

1. Pengaruh rasio utang Terhadap Kebijakan Dividen

Perusahaan yang memiliki perjanjian utang akan membatasi perusahaan membagikan dividen. Ada syarat yang harus dipenuhi oleh perusahaan yang memiliki utang agar perusahaan dapat selalu berada pada kondisi sehat. Hal ini menunjukkan bahwa kondisi kesehatan perusahaan memiliki pengaruh terhadap pembagian dividen perusahaan.

H1 : Debt equity ratio mempengaruhi kebijakan dividen

2. Pengaruh Pertumbuhan Laba Terhadap Kebijakan Dividen

Dividen dibagikan dari laba yang dihasilkan perusahaan. Laba yang menignkat menunjukkan kondisi kesempatan investasi yang besar yang dimiliki perusahaan. Hal inimembuat manajemen akan menggunakan laba tersebut untuk kepentingan pengembangan perusahaan. Akibatnya manajemen akan menahan laba tersebut untuk digunakan pada capital investment. Konsekuensinya laba ditahan menjadi besar dan dividen mengecil. Hal ini menunjukkan bahwa pertumbuhan laba mempengaruhi kebijakan dividen.

H2 : Pertumbuhan laba mempengaruhi kebijakan dividen

3. Pengaruh Rasio Profitabilitas Terhadap Kebijakan Dividen

Pada umumnya membagi dividen tergantung dari keberhasilan perusahaan menghasilkan laba. Dividen merupakan janji pengelola terhadap pemilik yang dianalogikan dengan kemampuan perusahaan menghasilkan laba dari sumber modal sendiri. Laba yang dibagikan tergantung pada kemampuan perusahaan mengelola dana pemilik untuk menghasilkan laba.

H3 : Return on equity mempengaruhi kebijakan dividen

4. Pengaruh Rasio Efisiensi Terhadap Kebijakan Dividen

Besar tidaknya pembagian dividen dilihat dari besar kecilnya laba yang dihasilkan. Perusahaan dapat menghasilkan laba jika ia mampu melaksanakan proses bisnis yang efisien sehingga proses ini mampu menghasilkan sisa dari penjualan yang dapat dikembalikan kepada manajemen. Kebijakan dividen merupakan cerminan efisiensi yang dilakukan oleh manajemen dalam mengelola perusahaannya.

$\mathrm{H} 4$ : Operating profit margin mempengaruhi kebijakan dividen

\section{Penelitian Terdahulu}

Hery (2009) meneliti tentang hubungan antara laba bersih dan arus kas operasi terhadap dividen kas. Penelitian tersebut menggunakan data dari data base OSIRIS (public listed companies worldwide) dengan data laporan keuangan dan 
laporan arus kas tahun 2007. Pemilihan sampel menggunakan teknik convenience sampling dan terpilih 25 perusahaan sampel. Teknik analisis data menggunakan analisis deskriptif Pearson,s correlation dengan variabel independen laba bersih dan arus kas operasi dan variabel dependennya adalah dividen kas. Hasil penelitian menunjukkan hubungan yang positif signifikan antara laba bersih dan dividen kas. Begitu juga hasil penelitian yang lain didukung yaitu arus kas operasi memliki hubungan positif signifikan dengan dividen kas.

Putra dan Yunia (2011) meneliti tentang faktor-faktor yang mempengaruhi keputusan pembagian dividen. Penelitian ini menggunakan perusahaan yang terdaftar di bursa efek kecuali sektor keuangan. Sampel dipilih dengan menggunakan teknik simple random sampling sebanyak 152 perusahaan atau $51,18 \%$ dari populasi. Data dikumpulkan dari laporan keuangan tahun 2009 yang berasal dari IDX. Metode analisis data menggunakan analisis regresi logistik dengan variabel independen dengan 1 untuk perusahaan yang membagi dividen dan 0 untuk perusahaan yang tidak membagi. Hasil menunjukkan bahwa volatilitas ROE dan keputusan pembagian dividen tahun lalu menentukan secara signifikan kebijakan pembagian dividen. Variabel lainnya seperti Laba ditahan, ROE, ukura perusahaan, DER, dan struktur kepemilikan tidak mempengaruhi pembagian dividen.

Suharli (2006) meneliti tentang pengaruh profitabilitas, leverage dan harga saham terhadap dividen kas. Penelitian ini menggunakan perusahaan yang terdaftar di BEJ tahun 20022003. Teknik pemilihan sampel menggunakan purposive sampling dan mendapatkan 62 perusahaan sampel. Data penelitian menggunakan laporankeuangan tahun 20022003. Teknik analisis data menggunakan analisis regresi dengan variabel dependen DPR dan variabel independennya adalah ROE, DER dan harga saham. Hasil menunjukkan bahwa ROE dan harga saham mempengaruhi DPR dengan tanda positif sedangkan DER memiliki arah hubungan yang negatif namun tidak signifikan mempengaruhi DPR.

Khazanah (2009) meneliti tentang pengaruh investasi, likuiditas, profitabilitas dan ukuran perusahaan terhadap kebijakan dividen. Sampel penelitian ini sebanyak 30 perusahaan dengan menggunakan teknik purposive sampling. Analisis menggunakan metode regresi linier berganda. Data menggunakan periode waktu 2000-2004. Hasil penelitian menunjukkan bahwa variabel profitabilitas mempengaruhi secara signifikan DPR, sedangkan variabel independen lainnya tidak signifikan mempengaruhi DPR. Namun jika dilihat dari nilai $F$ maka dapat disimpulkan bahwa semua variabel independen tersebut secara bersaman-sama mempengaruhi DPR.

Hidayat (2006) tentang pengaruh ROI, cash ratio, current ratio, debt to total asset, EPS dan size terhadap dividen kas. Penelitian ini menggunakan teknik purposive sampling dan sampelnya adalah 21 emiten. Sumber data menggunakan Indonesian Capital Market Directory 2004 dan 2005. Teknik analisis yang digunakan adalah analisis regresi berganda. Hasil menunjukkan ada dua variabel yaitu current ratio dan EPS yang mempengaruhi secara signifikan dividen kas. Sedangkan variabel lain tidak signifikan mempengaruhi dividen kas.

\section{METODE PENELITIAN}

Populasi penelitian ini adalah perusahaan emiten yang terdaftar di Bursa Efek Indonesia dengan kerangka sampel daftar 50 leading companies in market capitalization dari buku fact book Bursa Efek Indonesia tahun 2012. Pemilihan sampel menggunakan teknik purposive sampling dengan kriteria pertama, emiten tersebut minimal pernah dua kali membagikan 
dividen selama periode pengamatan dari tahun 2009 sampai dengan 2011. Kriteria kedua adalah emiten tersebut menerbitkan saham perdana atau IPO sebelum tahun 2010. Jadi jumlah sampel yang digunakan dalam proses pengolahan data sebanyak 36 emiten yang dapat dilihat pada lampiran 1. Semua data diperoleh dari dua sumber yaitu Indonesian Capital Market Directory (ICMD) tahun 2012 dan www.idx.co.id. Periode data yang dikumpulkan sama dengan periode penelitian yaitu 3 tahun yang meliputi tahun 2008 sampai dengan 2010.

Penelitian ini memiliki lima variabel yang terdiri dari satu variabel dependen dan empat variabel independen. Variabel dependennya adalah kebijakan dividen (DPR) yang diukur dengan menggunakan proporsi laba bersih tahunan yang dibagikan kepada pemegang saham perusahaan. Variabel independennya adalah likuiditas (DER), pertumbuhan (GROW), profitabilitas (ROE), dan efisiensi(OPM). Variable likuiditas diukur dengan menggunakan rasio debt to equity dan variabel pertumbuhan dihitung dengan rumus selisih laba tahun ini dengan tahun lalu dibagi laba tahun lalu. Pengukuran variabel profitabilitas menggunakan rasio return on equity sedangkan efisiensi diukur dengan menggunakan rasio operating profit margin.

Analisis data penelitian menggunakan metode regresi berganda. Model persamaan regresi pada penelitian ini adalah $\mathrm{DPR}=\mathrm{a}+\mathrm{b}_{1}$ $\mathrm{DER}+\mathrm{b}_{2} \mathrm{GROW}+\mathrm{b}_{3} \mathrm{ROE}+\mathrm{b}_{4} \mathrm{OPM}+\mathrm{u}$

Untuk memastikan bahwa model regresi yang dibuat dapat digunakan untuk menguji hipotesis maka dilakukan pengujian model. Sebelum pengujian hipotesis terlebih dahulu dilakukan maka persamaan regresi yang digunakan harus terbebas dari permasalahan normalitas, multikolinieritas, heteroskedastisitas, dan autokorelasi. Permasalahan tersebut sering disebut dengan asumsi klasik. Pengujian hipotesis penelitian ini menggunakan signifikansi dari nilai t dari persamaan regresi. Jika siginifikansi lebih kecil dari 5\% maka hipotesis nol ditolak sedangkan jika signifikansi lebih besar dari $5 \%$ maka hipotesis nol yang diterima. Semua pengolahan data pada penelitian ini menggunakan software SPSS versi 16.

\section{HASIL PENELITIAN DAN PEMBAHASAN}

\section{Statistik Deskriptif}

Perusahaan sampel memiliki dividen payout rat-rata $41,89 \%$ yang berarti $41 \%$ laba dibagikan kepada pemegang saham. Payout ini relatif tinggi karena hampir mencapai $50 \%$. Rata-rata perusahaan sampel memilik struktur modal yang menggunakan utang sebagai sumber pendanaan. Hal ini terlihat dari nilai rata-rata DER sebesar 2,2107. Ini menunjukkan bahwa komposisi utang besarnya 2 kali nilai ekuitas. Kemudian pertumbuhan rata-rata perusahaan sampel cukup baik yaitu sebesar 52, 7227\%. Untuk kinerja, statistik menunjukkan perusahaan sampel memiliki kinerja yang baik. Rata-rata ROE perusahaan sampel relatif tinggi yaitu sebesar 35,9042\% dengan rata-rata efisiensinya sebesar $26,8961 \%$. Hasil statistik deskriptif dapat dilihat pada tabel 1

Tabel 1

Statistik Deskriptif

\begin{tabular}{|l|l|l|l|l|}
\hline Variabel & Minimum & Maksimum & Mean & Deviasi Standar \\
\hline Divien payout ratio & 0,00 & 121,38 & 41,8988 & 28,28096 \\
\hline Debt equity ratio & 0,15 & 10,88 & 2,2107 & 2,94045 \\
\hline Pertumbuhan laba & $-74,58$ & 882,72 & 52,7227 & 113,60080 \\
\hline Return on equity & 4,49 & 151,45 & 35,9042 & 23,86821 \\
\hline $\begin{array}{l}\text { Operating profit } \\
\text { margin }\end{array}$ & 6,74 & 54,12 & 26,8961 & 11,28266 \\
\hline
\end{tabular}

Sumber: hasil olah data

\section{Hasil Pengujian Asumsi Klasik}

Pengujian normalitas menggunakan uji Kolmogorov-Smirnov. Pengujian terhadap residual persamaan regresi ini menghasilkan nilai $\mathrm{Z}$ sebesar 0,893 dengan $\mathrm{p}$-value 0,402 . Nilai p-value ini lebih besar dari alpha 0,05 sehingga dapat dikatakan bahwa distribusi residual tidak berbeda dengan distribusi normal. Jadi dapat disimpulkan bahwa persamaan regresi 
ini memenuhi asumsi normalitas. Pengujian multikolineritas menggunakan nilai VIF. Angka VIF dari variable independen berkisar antara 1,036 sampai dengan 1,058 yang berarti lebih kecil dari 10. Dari hasil ini dapat disimpulkan bahwa dalam persamaan regresi ini variable independen tidak saling berkorelasi atau dapat dikatakan persamaan regresi ini memenuhi asumsi mulikolinieritas.

Langkah selanjutnya adalah menguji autokorelasi dengan menggunakan nilai DurbinWatson. Nilai Durbin-Watson dari model regresi ini sebesar 1,453 yang artinya mendekati angka 2 sehingga dikatakan model regresi ini tidak terjadi autokorelasi. Pengujian asumsi klasik yang terakhir adalah heteroskedastisitas. Pengujian heteroskedastisiatas menggunakan uji Glesjer. Uji Glesjer merupakan pengujian regresi antara semua variabel independen dengan nilai absolute residual. Hasil uji Glesjer menunjukkan bahwa nilai $\mathrm{p}$-value tertinggi berasal dari variabel $\mathrm{ROE}$ sebesar 0,926 dan yang terendah dari variabel DER sebesar 0,118. Hal ini berarti p-value (sign) dari setiap koefisien persamaan lebih besar dari alpha 0,05 dan dapat disimpulkan bahwa model regresi terbebas dari masalah heteroskedastisitas.

\section{Hasil Persamaan Regresi}

Hasil analisis regresi dapat dilihat pada tabel 2 dengan model persamaan regresinya adalah: DPR $=23,112-3,326$ DER -0,35 GROW $+0,473 \mathrm{ROE}+0,42 \mathrm{OPM}$

Model persamaan regresi ini menunjukkan bahwa jika semua variabel independen konstan maka besar nilai DPR adalah 23,112\%. Dari persamaan tersebut terlihat bahwa ada dua variabel indepeden yang nilai koefisiennya negatif dan dua variabel lainnya bernilai positif.

Koefisien variabel DER menunjukkan tanda negatif sehingga dapat dapat dikatakan bahwa semakin tinggi angka DER maka semakin rendah nilai DPR. Begitu juga dengan variabel pertumbuhan laba yang mempunyai nilai koefisien negatif yang berarti semakin besar pertumbuhan laba maka semakin rendah nilai DPR.

Tabel 2

\section{Hasil Pengolahan Data Persamaan Regresi}

\begin{tabular}{|lccc|}
\hline \multicolumn{1}{|c}{ Variabel } & Koefisien & t & Sign \\
\hline Konstanta & 23,112 & 3,3467 & $0,001^{* * *}$ \\
\hline Debt equity ratio & $-3,326$ & -4267 & $0,000^{* *} *$ \\
\hline Pertumbuhan laba & $-0,035$ & $-1,739$ & $0,085^{* *}$ \\
\hline Return on equity & 0,473 & 4,882 & $0,000^{* * *}$ \\
\hline Operating profit margin & 0,420 & 2,062 & $0,042^{* * *}$ \\
\hline
\end{tabular}

Sumber : hasil olah data

*** signifikan pada $95 \%$, ** signifikan pada $90 \%$

Variabel yang memiliki koefisien postitif adalah ROE dan OPM. Dari tabel 3.4 dapat dilihat bahwa koefisien ROE dan OPM sebesar 0,473 dan 0,42. Koefisen positif menunjukkan bahwa semakin tinggi angka ROE maka semakin besar nilai DPR dan semakin tinggi OPM maka semakin tinggi nilai DPR.

Tabel 3

Ringkasan Model Regresi

\begin{tabular}{|l|c|}
\hline \multicolumn{1}{|c|}{ Keterangan } & Nilai \\
\hline R square & 0,342 \\
\hline Nilai F & 13,244 \\
\hline Sign. Nilai F & 0,000 \\
\hline
\end{tabular}

Sumber: hasil olah data

Hasil pengolahan data pada tabel 3 menunjukkan bahwa nilai $\mathrm{R}^{2}$ untuk model regresi yang digunakan sebesar 0,342. Hal ini berarti variabel-variabel independen mampu menjelaskan variabel dependen sebesar 34,2\%. Jadi hasil ini menunjukkan bahwa sebesar 34,2\% variabel DPR dapat dijelaskan oleh DER, pertumbuhan laba, ROE dan OPM. Nilai F dari model regresi ini sebesar 13,244 dengan p-value (sign) 0,00. Angka p-value yang lebih kecil dari alpha 0,05 menunjukkan bahwa variabel dependen secara bersama-sama mempengaruhi variabel dependen. Jadi dapat disimpulkan bahwa variabel DER, pertumbuhan laba, ROE dan OPM secara bersama-sama mempengaruhi DPR.

\section{Hasil Pengujian Hipotesis}

Penelitian ini menguji 4 hipotesis. Hasil pengujian hipotesis dapat dilihat pada tabel 2 . 
Dari hasil pengolahan data dapat dilihat bahwa nilai t pada pengujian hipotesis pertama sebesar -4,267 dengan p-value (sign) 0,000. Hal ini berarti hipotesis satu diterima. Jadi dapat disimpulkan bahwa dengan tingkat keyakinan 95\% variabel DER mempengaruhi kebijakan dividen secara signifikan.

Pengujian hipotesis kedua menunjukkan bahwa nilai $\mathrm{t}$ sebesar -1,739 dengan $\mathrm{p}$-value (sign) 0,085 . Nilai p-value variabel ini lebih besar dari alpha 0,05 sehingga dapat dikatakan bahwa hipotesis dua ditolak. Jadi dapat disimpulkan bahwa dengan tingkat keyakinan $95 \%$ variabel pertumbuhan laba secara signifikan tidak mempengaruhi kebijakan dividen. Namun jika tingkat keyakinan yang digunakan adalah $90 \%$ maka hasil hipotesis kedua dapat diterima.

Hipotesis tiga dan empat menunjukkan hasil yang sama. Nilai t untuk hipotesis ketiga dan keempat sebesar 4,882 dan 2,063, sedangkan p-valuenya (sign) sebesar 0,000 dan 0,42. Berdasarkan angka p-value (sign) yang lebih kecil dari alpha 0,05 maka dapat dikatakan hipotesis tiga dan empat diterima. Jadi dapat disimpulkan untuk hipotesis ketiga bahwa dengan tingkat keyakinan 95\% variabel ROE secara signifikan mempengaruhi kebijakan dividen, sedangkan hasil hipotesis keempat menunjukkan bahwa dengan tingkat keyakinan $95 \%$ variabel OPM mempengaruhi kebijakan dividen secara signifikan.

Dividen merupakan bentuk imbal jasa yang diberikan perusahaan kepada pemegang saham yang menginvestasikan uangnya didalam bisnis perusahaan. Pembagian dividen merupakan indikator keberhasilan manajemen mengelola perusahaan. Namun disisi lain jika semua laba bersih perusahaan dibagikan maka potensi perusahan untuk berkembang juga akan berkurang. Oleh sebab itu manajemen harus memiliki pertimbangan yang tepat berapa dari laba yang dihasilkan itu dibagikan kepada pemegang saham. Besarnya laba yang dibagikan kepada pemegangan saham itulah yang disebut kebijakan dividen.

Hasil pengolahan data menunjukkan bahwa secara bersama-sama variabel ROE, pertumbuhan laba, ROE dan OPM mempengaruhi kebijakan dividen. Penelitian ini mengenai konsisten dengan penelitian Uswatun Khazanah (2006) dan Michell Suherli (2006) dan berbeda dengan Chandra dan Yunia (2011). Hal ini menunjukkan bahwa pertimbangan manajemen dalam menentukan besar laba yang dibagikan dipengaruhi oleh kondisi keuangan perusahaan yang meliputi likuiditas, potensi pertumbuhan, profitabilitas dan efisiensi. Kesalahan memahami kondisi keuangan perusahaan akan menghasilkan kebijakan dividen yang kurang menguntungkan untuk perkembangan perusahaan kedepan. Laba merupakan sumber pendanaan internal perusahaan atau bisa dikatakan sumber dana mandiri. Oleh sebab itu penggunaan laba untuk dikembalikan ke pemegang saham atau direinvestasikan ke perusahaan sangat tergantung dari kondisi likuiditas, profitabiltas dan efisiensi bisnis perusahaan.

Variabel DER mempengaruhi kebijakan dividen. Hasil ini tidak konsisten dengan penelitian Chandra dan Yunia (2011). Hasil penelitian ini menunjukkan bahwa semakin besar nilai DER semakin rendah kebijakan dividen. Manajemen dalam membuat kebijakan dividen mempertimbangkan tingkat likuiditas atau struktur modal perusahaan. Jika perusahaan memiliki utang yang relatif tinggi maka perusahaan harus memiliki jaminan aktiva yang cukup. Oleh sebab itu bagi perusahaan yang memiliki keadaan yang seperti itu maka tidak semua laba akan dibagikan ke pemengang saham. Hal ini akan mempengaruhi keputusan manajemen dalam menentukan kebijakan dividen.

Pertumbuhan laba pada tingkat keyakinan 90\% dapat disimpulkan mempengaruhi kebijakan dividen. Dari tanda koefisien yang negatif maka kita dapat dikatakan bahwa pengaruh 
pertumbuhan laba terhadap kebijakan dividen adalah berlawanan arah. Pertumbuhan laba yang besar menunjukkan potensi bisnis perusahaan yang besar. Artinya kondisi bisnis perusahaan baik sehingga peluang untuk mengembangkan perusahaan juga tinggi. Untuk mengembangkan perusahaan dibutuhkan dana. Salah satu sumber pendanaan internal adalah laba. Kondisi pertumbuhan laba akan mempengaruhi keputusan manajemen untuk membagikan dividen karena jika kondisi seperti itu maka dana laba tersebut akan lebih bermanfaat jika direeinvestasikan kembali ke dalam kegiatan operasi perusahaan dari pada dibagikan ke pemegang saham.

Profitabilitas dan efisiensi juga mempengaruhi kebijakan dividen perusahaan. Profitabilitas berkaitan dengan keputusan pendanaan dan kegiatan operasi perusahaan. Keputusan pendanaan adalah seberapa besar komposisi penggunaan dana dari pihak luar dan pihak pemilik. Kebijakan dividen merupakan daya tarik bagi pemegangan saham untuk berinvestasi di perusahaan tersebut. Kemampuan perusahaan menghasilkan laba dari sumber dana pemegang saham memberikan tanda kemampuan perusahaan untuk memberikan imbalan kepada pemegang saham. Kemudian kemampuan perusahaan melakukan efisien yang dilihat dari rasio OPM maka sisa pendapatan yang dibagikan kepada pemegang saham juga akan semakin besar.

\section{KESIMPULAN DAN SARAN}

\section{Simpulan}

Hasil pengujian menunjukkan bahwa DER, ROE dan OPM mempengaruhi kebijakan dividen. Sedangkan untuk pertumbuhan laba dapat disimpulkan juga bahwa dengan tingkat keyakinan yang sedikit lebih rendah dapat dikatakan pertumbuhan laba mempengaruhi kebijakan divi den. Jika dilihat dari kondisi perusahaan, semakin tinggi struktur modal dan pertumbuhan laba maka kebijakan dividen akan semakin rendah. Namun dari sisi kinerja perusahaan terlihat bahwa semakin tinggi profitabilitas dan efisiensi perusahaan maka manajemen akan menetapkan kebijakan dividen yang semakin tinggi.

Hasil penelitian menunjukkan bahwa kondisi dan kinerja keuangan perusahaan mempengaruhi kebijakan dividen perusahaan. Bagi perusahaan dividen bisa menjadi daya tarik untuk menarik investor baru berinvestasi pada bisnis perusahaan tersebut. Dividen juga dapat menjadi sumber dana yang efektif bagi perusahaan untuk mengembangkan atau menambah nilai perusahaan di kemudian hari. Jadi besar kecilnya pembagian dividen tergantung dari perkembangan kegiatan bisnis dan rencana jangka panjang perusahaan.

\section{Saran}

Penelitian dapat dilanjutkan dengan mencoba mencari variabel-variabel keuangan mana yang dapat digunakan untuk memprediksi perubahan kebijakan dividen. Kebijakan dividen dapat dijadikan sinyal yang efektif bagi perusahaankepada para investor sehingga perubahan kebijakan dividen dapat mengubah ekspektasi investor terhadap perusahaan.

Selain itu penelitian ini dapat dikembangkan dengan mengaitkan kebijakan dividen dengan beberapa variabel non keuangan. Kebijakan dividen diputuskan dalam Rapat Umum Pemegang Saham. Ini berarti besar dividen bukan hanya ditentukan oleh pihak manajemen tetapi juga oleh pemegang saham. Komposisi pemegang saham juga mempengaruhi kebijakan dividen. Selain itu kebijakan dividen juga berdampak pada rasio-rasio keuangan sehingga ada kemungkinan digunakan oleh manajemen untuk melakukan manajemen laba. 


\section{DAFTAR PUSTAKA}

Apriani, Lisia. 2005. Reaksi Pasar Terhadap Pengumuman Kenaikan/Penurunan Dividen (Studi Empiris Pada Perusahaan Utilitas Publik dan Perusahaan dalam Industri Tidak Diregulasi). Procceding Simposium Nasional Akuntansi VIII. Solo, 15 - 16 September 2005. Hal 75 -86 .

Bandi dan Jogiyanto Hartono. 2000. Perilaku Reaksi Harga dan Volume Perdagangan Saham Terhadap Pengumuman Dividen. Jurnal Riset Akuntansi Indonesia. Vol. 3, No. 2. Juli 2000. Hal 203 - 213.

Basir, Saleh dan Hendy M. Fakhruddin 2005. Aksi Korporasi: Strategi untuk Meningkatkan Nilai Saham Melalui Aksi Korporasi. Edisi 1. Salemba Empat. Jakarta.

Deitiana, Tita. 2011. Pengaruh Rasio Keuangan Pertumbuhan Penjualan dan Dividen Terhadap Harga Saham. Jurnal Bisnis dan Akuntansi. Vol. 13, No 1, April 2011. Hal 57 - 66 .

Habbe, Abd. Hamid. 2003. Tambahan Kandungan Informasi Perubahan Dividen Tentang Profitabilitas Perusahaan Dimasa yang Akan Datang. Procceding Simposium Nasional Akuntansi. Surabaya, 16 - 17 Oktober 2003. Hal 473 - 486.

Hery. 2009. Hubungan Antara Laba Bersih Dan Arus Kas Operasi Terhadap Dividen Kas. Akuntabilitas. Vol. 9 No. 1, September 2009. Hal 10 - 16.

Hidayat, Nur. 2006. Analisis Faktor-Faktor yang Mempengaruhi Dividen Kas di Bursa Efek Jakarta. Skripsi. Fakultas Ekonomi Universitas Islam Indonesia. Yogyakarta.

Khazanah, Uswatun. 2009. Analisis Pengaruh Investasi. Likuiditas, Profitabilitas dan Ukuran Perusahaan Terhadap Kebijakan Dividen Payout Ratio Pada Perusahaan yang Terdaftar di Jakarta Islamic Index Tahun 2000 - 2004. Skripsi. Fakultas Syariah UIN Sunan Kalijaga. Yogyakarta.

Pujiono. 2002. Dampak Kebijakan Dividen Terhadap Harga Saham pada Waktu ExDividen Day. Jurnal Riset Akuntansi Indonesia. Vol. 5, No. 2, Mei 2002. Hal $148-161$.

Putra, Chandra Dwi dan Yunia Panjaitan. 2011. Analisis Faktor-Faktor yang Mempengaruhi Keputusan Pembagian Dividen Pada Perusahaan yang Terdaftar di Bursa Efek Indonesia Tahun 2009. Telaah Manajemen. Vol. 6, No.2, November 2011. Hal $104-124$

Setyawan, Ignatius Roni. 2009. Interaksi Keputusan Dividen dan Struktur Modal: Deteksi Pelaksanaan Efektifitas GCG Saham LQ45. Akuntabilitas. Vol. 9, No. 1, September 2009. Hal 63 - 72.

Siaputra, Leni dan Adwin Surja Atmadja. 2006.

Pengaruh Pengumuman Dividen

Terhadap Perubahan Harga Saham Sebelum dan Sesudah Ex-Dividen Date di Bursa Efek Jakarta (BEJ). Jurnal Akuntansi dan Keuangan. Vol. 8, No. 1, Mei 2006. Hal 71 - 77.

Suharli, Michell. 2006. Pengaruh Profitabilitas, Leverage Dan Harga Saham Terhadap Dividen Kas. Jurnal Maksi. Vol. 6, No. 2, Agustus 2006. Hal $224-242$.

Sularso, R. Andi. 2003. Pengaruh Pengumuman Dividen Terhadap Perubahan Harga Saham (Return) Sebelum dan Sesudah Ex-Dividen di Bursa Efek Jakarta (BEJ). Jurnal Akuntansi dan Keuangan. Vol 5, No. 1, Mei 2003. Hal 1 - 17.

Walsh, Ciaran. 2003. Key Management Ratios: Rasio-Rasio Manajemen Penting Penggerak dan Pengendali Bisnis. Edisi ke-3. Penerjemah: Shalahuddin Haikal. Erlangga. Jakarta. 


\section{LAMPIRAN}

\section{Daftar Sampel Penelitian}

\begin{tabular}{|c|c|c|}
\hline No & Kode & Nama Sampel \\
\hline 1 & AALI & PT. Astra Agro Lestari, Tbk. \\
\hline 2 & ADRO & PT. Adaro Energi, Tbk. \\
\hline 3 & ANTM & PT. Aneka Tambang, Tbk. \\
\hline 4 & ASII & PT. Astra Internasional, Tbk. \\
\hline 5 & BUMI & PT. Bumi Resources, Tbk. \\
\hline 6 & CPIN & PT. Charoen Pokpahand Indonesia, Tbk. \\
\hline 7 & EXCL & PT. XL Axiata, Tbk. \\
\hline 8 & GGRM & PT. Gudang Garam, Tbk. \\
\hline 9 & INCO & PT. Vale Indonesia, Tbk. \\
\hline 10 & INDF & PT. Indofood Sukses Makmur, Tbk. \\
\hline 11 & INTP & PT. Indocement Tunggal Prakarsa, Tbk. \\
\hline 12 & ITMG & PT. Indo Tambangraya Megah, Tbk. \\
\hline 13 & JSMR & PT. Jasa Marga (Persero), Tbk. \\
\hline 14 & KLBF & PT. Kalbe Farma, Tbk. \\
\hline 15 & LSIP & PT. PP London Sumatera Indonesia, Tbk. \\
\hline 16 & $\mathrm{MNCN}$ & PT. Media Nusantara Citra, Tbk. \\
\hline 17 & PGAS & PT. Perusahaan Gas Negara (Persero), Tbk. \\
\hline 18 & PTBA & $\begin{array}{l}\text { PT. Tambang Batubara Bukit Asam (Persero), } \\
\text { Tbk. }\end{array}$ \\
\hline 19 & SMGR & PT. Semen Gresik (Persero), Tbk. \\
\hline 20 & TLKM & PT. Telekomunikasi Indonesia (Persero), Tbk. \\
\hline 21 & UNTR & PT. United Tractors, Tbk. \\
\hline 22 & UNVR & PT. Unilever Indonesia, Tbk. \\
\hline 23 & BMTR & PT. Global Mediacom, Tbk. \\
\hline 24 & HMSP & PT. HM Sampoerna, Tbk. \\
\hline 25 & ISAT & PT. Indosat, Tbk. \\
\hline 26 & SCMA & PT. Surya Citra Media, Tbk. \\
\hline 27 & SMAR & PT. SMART, Tbk. \\
\hline 28 & $\mathrm{BBCA}$ & PT. Bank Central Asia, Tbk. \\
\hline 29 & BBNI & PT. Bank Negara Indonesia (Persero), Tbk. \\
\hline 30 & BBRI & PT. Bank Rakyat Indoensia (Persero), Tbk. \\
\hline 31 & BDMN & PT. Bank Danamon Indonesia, Tbk. \\
\hline 32 & BMRI & PT. Bank Mandiri (Persero), Tbk. \\
\hline 33 & BSDE & PT. Bumi Serpong Damai, Tbk. \\
\hline 34 & LPKR & PT. Lippo Karawaci, Tbk. \\
\hline 35 & BNGA & PT. Bank CIMB Niaga, Tbk. \\
\hline 36 & SMMA & PT.Sinar Mas Multiartha, Tbk. \\
\hline
\end{tabular}

